\title{
THE EFFICIENCY OF USING PEAT AS A FEED SUPPLEMENT IN COMPOUND FEED FOR CHICKENS
}

\author{
Caisin Larisa \\ Doctor of Agricultural Sciences, Professor \\ State Agrarian University of Moldova \\ Director of the Department of Animal Management and Agri-food Security \\ ORCID: 0000-0001-8934-2709 \\ Email: caisinlarisa@mail.ru
}

In recent years, interest in the use of peat as a feed supplement has increased, particularly due to its capacity to prevent enteric diseases and to stimulate growth in animals and poultries. Peat is an easily available natural material and a source of biologically active substances widely used, not only in agriculture but in human and animal medicine as well. Biological activity of various peat preparations is associated not only with fluctuations in the chemical compositions, but also with different application techniques. experiment was carried out on two groups of poultry under the conditions of a poultry farm in the Republic of Moldova. Its purpose was to determine the use of a feed supplement - peat concentrate as a new unconventional feed ingredient in the composition of mixed feed for laying hens and its influence on their egg production, average weight and category of eggs. The objectives of the study included the study of the chemical composition of the peat supplement and the determination of the effect of peat powder additive on the egg production. The effect of the dosage of the peat preparation in the amount of 1\% (experimental group) was studied and the obtained results were compared with the control group, in which the laying hens consumed the basic compound feed. The high concentration of active ingredients and the uniqueness of the components of the peat feed supplement, the adsorbing properties due to the presence of humic acids and lignin in its composition, made it possible to increase the natural immune response in laying hens by increasing the egg production of laying hens by 7.2\%; by improving the quality of products such as the average egg weight by $4.72 \%$; egg mass by $12.6 \%$; the height of the egg white by $23.96 \%$; the width of the egg white by $2.14 \%$; and an increase in colour intensity by 0.43 units, while reducing the cost of food.

Keywords: peat, feed supplement, laying hens, eggs

DOI: https://doi.org/10.32845/bsnau.lvst.2021.2.4

Poultry farming is one of the most intensive and dynamic branches of the agro-industrial complex among the priority branches of animal husbandry due to the early maturity and high meat and egg productivity of poultry with relatively low feed costs. The development of the poultry industry in the Republic of Moldova, as well as in the world, shows a clearly pronounced trend towards an increase in the share of products in the total mass of livestock products [7].

The main direction of production intensification in poultry farming is the implementation of the genetic potential of poultry. At the same time, the high egg productivity of chickens depends on many factors (breed, adherence to keeping technology, age, health status, season, etc.), however, the most important of all factors is feeding.

At present, great importance is attached to the use of ecologically safe, biologically active elements and preparations in poultry feeding that have a positive effect on their biochemical, immunological, hematological and productive indicators [3].

However, there is practically no information on the effectiveness of the use of peat preparations as feed ingredients in feeding poultry, in particular, in laying hens. Peat is a natural organic material with various properties, which in its composition contains natural humic acids, which have a stimulating effect on the development of useful microflora and which has an unrivaled advantage: purity and sterility (there is completely no pathogenic microflora, pathogens, industrial pollution). According to a number of authors, organic and inorganic substances in peat are in harmony, combining into a certain chemical "bouquet" [8].

Individual components of peat organic matter are unequal in biological activity, the activity of humic preparations has been studied to the greatest extent [2].

The history of the study of humic substances is more than two hundred years old. For the first time the German chem-

ist $F$. Achard isolated them from peat and reported about them in 1786 [11]. Therefore, German scientists developed the first schemes for the isolation and classification of humic substances, and also introduced the term itself - "humic ".

Humic acids and the creation on their basis of environmentally friendly organic feed supplements for poultry, farm animals and fish are one of the promising areas for the use of peat and its derivatives, which determine its practical value [9]. The studies carried out by scientists from different countries have shown that humic substances in the body of an animal or of a plant work at the cellular and subcellular level. They penetrate into the cell and participate in metabolic processes, optimizing them, they facilitate the passage of inorganic ions through the intestinal walls, facilitating the absorption of minerals necessary for the normal functioning of the body. Thereby, the stimulating effect of humic substances on individual systems and the body as a whole is manifested $[14,15]$.

The use of peat is also relevant because of its adsorptive properties, which are also due to the presence of humic acids and lignin in it; they are capable of absorbing heavy metal ions and toxins. The adsorption properties of peat are associated with the presence of functional groups in the structure covalently bound to the matrix: amine, amide, alcohol, aldehyde, carboxyl, carboxylate, ketone, phenolic, quinone, peptide and methoxyl. Also, the adsorptive properties of peat are due to the presence of polymolecular associates characterized by a more or less definite organization at the macrolevel, in particular humic substances (mainly humic and fulvic acids) and lignin [10].

Bioregulators of humic nature meet all the requirements for feed preparations: they are relatively cheap, metabolized with food or water in the body after ingestion, do not accumulate in organs and tissues, belong to the category of environmentally 
friendly [4]. It has been proved that preparations obtained from peat are not toxic and not teratogenic [6].

Modern scientific research has established that humic peat preparations are harmless to animals and humans, do not have allergenic, anaphylactogenic, teratogenic, embryotoxic and carcinogenic effects when used in recommended doses. Peat preparations activate the digestive and metabolic processes in the body of animals, contributing to the transformation of feed nutrients into digestible forms, increasing daily milk yield and weight gain, they can play an important role in solving the urgent task of expanding the range of ecological cheap preparations. The possibilities of using peat preparations in animal husbandry are diverse, but their use as feed supplements is not well developed.

Material and method of research. In 2019 an experiment was carried out on two groups of poultry [12] under the conditions of a poultry farm in the Republic of Moldova. Its purpose was to determine the use of a feed supplement

- peat concentrate as a new unconventional feed ingredient in the composition of mixed feed for laying hens and its influence on their egg production, average weight and category of eggs.

The objectives of the study included the study of the chemical composition of the peat supplement and the determination of the effect of peat powder additive on the egg production. The effect of the dosage of the peat preparation in the amount of $1 \%$ (experimental group) was studied and the obtained results were compared with the control group, in which the laying hens consumed the basic compound feed (Table 1).

Table 1

\begin{tabular}{|l|l|l|}
\hline & & Feeding features \\
\hline & 13000 & $\mathrm{~B}$ \\
\hline & 13000 & $\mathrm{BF}+1,0 \mathrm{~kg} / \mathrm{t}$ peat feed concentrate \\
\hline
\end{tabular}

According to the recommendations, the conditions of feeding, drinking, housing and microclimate parameters in the experimental groups were the same.

During the experiment, the egg production per average laying hen was taken into account and determined by dividing the gross collection of eggs for a certain period by the average number of laying hens for this period.

The intensity of egg production is a widespread operational method of expressing the egg production of hens over a period of time and it is expressed in percentage. The quality of eggs was assessed by the state of the shell and the air cell, its height, density and mobility of the egg white and yolk. During the ovoscopy, the egg was slowly rotated around the major and then the minor axis in front of the light window of the ovoscope. Egg weight is an indicator calculated by multiplying the number of laid eggs by their average weight. The average egg weight per hen was calculated using the formula: Average number of eggs for the period $\times$ average weight of eggs for the period, $g$ [9].

The morphological parameters of eggs, under the influence of various factors, are subject to significant variability, but morphological characters are distinguished by the greater variability. Egg mass is the most important physical indicator of nutritional and market value, which determines the productivity of poultry. The weight of the eggs was determined by weighing them to the nearest 0.1 gram.
There is a close correlation between the thickness of the shell and its strength. For direct measurement of the shell thickness, measurement was made at three points of the egg: in the middle part, broad and sharp ends. Before the measurement, the under shell layers were removed.

Feed consumption was determined by periodic and daily group recording of feed consumption and residues. Feed costs per 1 kilogram of egg mass were calculated as follows: Feed costs for the period / weight of eggs $x$ number of eggs.

The data obtained in the experiment were processed biometrically using a computer, test was performed on data showing significance among treatment means $(P \leq 0.05)$ [44]. Significance was accepted at a $P \leq 0.05$ [15].

Results and discussion. The main product of agricultural poultry is the egg [11]. Egg production is the main indicator of the productivity of laying hens, it is determined by the number of eggs laid over a certain period of time, and depends on various external and internal factors. An important point that relates to the impact of the external environment and helps the manifestation of the genetic potential of the poultry and its ability to lay eggs is the process and quality of poultry feeding.

The determination of the chemical composition of the peat feed supplement, as well as the composition and nutritional value of feeds that were used in compound feeds for the experiment, was carried out in the laboratory of the Department of Management and Quality Control of Livestock Products of the State Agrarian University. The content of macro- and microelements in the studied feed supplement was studied at the Institute of Chemistry of the Academy of Sciences of Moldova; the amino acid composition was determined in the laboratory of the Institute of Physiology and Sanocreatology of the Academy of Sciences of Moldova.

When analyzing the chemical composition of the peat supplement (Table 2), it has been found out that the preparation contains organic matter $65.04 \%$, crude protein $5.06 \%$ and crude ash (mineral substances) $18.77 \%$.

Table 2

Chemical composition and nutritional value of dry peat supplement, \%

\begin{tabular}{|l|c|}
\hline \multicolumn{1}{|c|}{ In } & Peat supplement \\
\hline \multicolumn{2}{|c|}{ In air dry state } \\
\hline Initial moisture & 11.70 \\
\hline Hygroscopic moisture & 5.09 \\
\hline Crude protein & 5.73 \\
\hline Crude fat & 2.26 \\
\hline Crude fiber & 14.46 \\
\hline Crude ash & 21.26 \\
\hline \multicolumn{2}{|c|}{ In the natural state } \\
\hline Dry matter & 83.81 \\
\hline Organic matter & 65.04 \\
\hline Crude protein & 5.06 \\
\hline Crude fat & 1.99 \\
\hline Crude fiber & 12.77 \\
\hline Crude ash & 18.77 \\
\hline NES & 45.21 \\
\hline OFU & 0.96 \\
\hline EE, MJ & 11.86 \\
\hline
\end{tabular}

Particular importance for maintaining normal life processes, metabolism and increasing the productivity of poultry is given to the microelements contained in feed in an easily available chelated form. At the same time, it is important to realize all 
the properties of these mineral elements, which in turn are associated with the form in which they are present in feed.

Organic microelements are assimilated better than inorganic ones, they do not reduce the effect of biologically active feed components, but only if the bond between the metal and the amino acid is preserved during passage through the gastrointestinal tract. The studied mineral composition of the peat supplement (Table 3) showed a high content of: iron - 2657.0, calcium - 2104.0, magnesium - 381.0 and potassium - $174.5 \mathrm{mg}$ $/ \mathrm{kg}$. This microelement is necessary for the synthesis of hemoglobin, which contains more than half of its reserves in the body.

Table 3

Characteristics of the chemical composition of organic peat feed concentrate by its macro-and micro mineral composition

\begin{tabular}{|l|c|}
\hline \multicolumn{1}{|c|}{ Indicators } & Dry / powder form, $\mathbf{~ m g ~ / ~ k g ~}$ \\
\hline Calcium $\left(\mathrm{Ca}^{2+}\right)$ & 2104.0 \\
\hline Magnesium $\left(\mathrm{Mg}^{2+}\right)$ & 381.0 \\
\hline Iron (Fe total) & 2657.0 \\
\hline Sodium (Na) & 56.0 \\
\hline Potassium $(\mathrm{K})$ & 174.5 \\
\hline Zinc $(\mathrm{Zn})$ & 8.2 \\
\hline Copper $(\mathrm{Cu})$ & 6.8 \\
\hline Manganese $(\mathrm{Mn})$ & 26.6 \\
\hline Nickel $(\mathrm{Ni})$ & 16.7 \\
\hline Cobalt $(\mathrm{Co})$ & 22.5 \\
\hline Chromium $(\mathrm{Cr})$ & 0.14 \\
\hline Cadmium $(\mathrm{Cd})$ & $<0.25$ \\
\hline Plumbum(Pb) & 2.0 \\
\hline Phosphates $\left(\mathrm{P}^{2} \mathrm{O}^{5}\right)$ & 480.3 \\
\hline
\end{tabular}

The level of iron in the peat supplement is quite high and exceeds its content in meat and bone and grass meal by $20157.0 \mathrm{mg} / \mathrm{kg}$, and as an oxygen carrier, this element helps to increase the metabolism of nutrients inside the cell, it is part of a number of enzymes: cytochrome, catalase and peroxidase. Lack of iron in the diet leads to the development of anemia, and in addition to anemia, a decrease in the level of iron in the liver is registered, where the activity of cytochromes remains almost unchanged. These data allow us to conclude that the peat supplement contains iron at a high level and in its accessible form, and therefore is of interest as a component that supplements this microelement in feed.

The content of cobalt in the peat supplement significantly exceeds its level in meat and bone meal by $1.8 \mathrm{mg} / \mathrm{kg}$ and in fish meal by $0.249 \mathrm{mg} / \mathrm{kg}$. Cobalt increases the activity of hydrolytic enzymes, increases the synthesis of nucleic acid and muscle proteins, and improves the functioning of hematopoietic organs. The physiological effect of cobalt is mainly due to its presence in the vitamin B12 molecule.

Peat flour is a source of essential amino acids with a high content of aspartic and glutamic acids, valine and tyrosine (Table 4).

When conducting the scientific and economic experiment, the basis of compound feed was made up of corn, wheat, soybean meal, sunflower cake, the rest of the compound feed was made up of feed supplements (Table 5).

In the experiment, laying hens were divided into two groups, each with 13000 heads per group, kept in the same environmental conditions, in the same feeding conditions and at the same age: one control group (CG) and one experimental group (EG).
Amino acid profile in peat feed supplement

\begin{tabular}{|l|c|l|}
\hline \multicolumn{1}{|c|}{ Amino acids } & Dry, $\mathbf{g} / \mathbf{k g}$ & Nitrogen, $\mathbf{g} / \mathbf{~ k g}$ \\
\hline Cysteic acid & 0.0983 & 0.0074 \\
\hline Taurine & 00414 & 0.0046 \\
\hline Aspartic acid & 1.2709 & 0.1337 \\
\hline Threonine & 1.0064 & 0.1183 \\
\hline Serine & 0.7789 & 0.1038 \\
\hline Glutamic acid & 1.5481 & 0.1473 \\
\hline Glycine & 1.1965 & 0.2231 \\
\hline Alanin & 1.3788 & 0.2167 \\
\hline Valine & 1.5592 & 0.1863 \\
\hline Cysteine & 0.4400 & 0.1025 \\
\hline Methionine & 0.1406 & 0.0132 \\
\hline Isolecin & 1.0262 & 0.1095 \\
\hline Leucine & 1.3354 & 0.1425 \\
\hline Tyrosine & 0.1694 & 0.0131 \\
\hline Pheninalanine & 0.7013 & 0.0594 \\
\hline Ornithine & 0.0846 & 0.0179 \\
\hline Lysine & 0.6527 & 0.1250 \\
\hline Histidine & 0.4207 & 0.1139 \\
\hline Arginine & 0.5446 & 0.1751 \\
\hline Ammonia & 0.4748 & 0.3903 \\
\hline
\end{tabular}

During the period of introduction of peat feed concentrate into the diet of laying hens, it was found out that the gross collection of eggs in the experimental group was higher than in the control group by 674.0 pieces, the greatest value of the mass of eggs was also noted in the experimental group, while the difference with the control group was 73.89 pieces (Table 6).

Composition of compound feed during

Table 5

\begin{tabular}{|l|r|}
\hline \multicolumn{1}{|c|}{ Indicators } & $\%$ \\
\hline Corn & 44.0 \\
\hline Wheat & 14.0 \\
\hline Soybean meal & 10.0 \\
\hline Sunflower meal & 3.5 \\
\hline Sunflower cake & 6.0 \\
\hline Soybean oil & 1.0 \\
\hline Shell rock & 10.0 \\
\hline Premix & 2.0 \\
\hline Chalk & 2.5 \\
\hline DL 68 & 1.5 \\
\hline
\end{tabular}

Table 6

Comparative characteristics of laying hens' egg production

\begin{tabular}{|l|r|c|}
\hline \multirow{2}{*}{\multicolumn{1}{|c|}{ Indicators }} & \multicolumn{2}{c|}{ Group } \\
\cline { 2 - 3 } & \multicolumn{1}{|c|}{ Control } & Experimental \\
\hline Number of eggs, pcs. & 25.35 & 3.42 \\
\hline Egg mass, kg & 9604.0 & 10278.0 \\
\hline Broken eggs, pcs. & 612.59 & 686.48 \\
\hline
\end{tabular}

Morphometric indicators of laying hens' eggs are one of the main indicators of their quality (Table 7). Relative to the control group, in the poultry of the experimental group there was a certain tendency to an increase by $0.5 \%$ of the egg mass, the egg white by $0.1 \%$, the yolk by $0.6 \%$, the egg shell by $2.5 \%$ and its thickness by $7,4 \%$, egg white height - by $1.2 \%$.

The average egg weight was $3.01 \mathrm{~g}$, egg mass - 73.89 $\mathrm{kg}$, egg width $-0.009 \mathrm{~cm}$, and length -

$0.089 \mathrm{~cm}$ compared to the control group with a difference of $7.02,4.72,12.06,0$, respectively 20 and $1.50 \%$ (Tables 
Technological features of eggs

\begin{tabular}{|c|c|c|c|c|c|c|c|c|c|}
\hline \multirow[b]{2}{*}{ Group } & \multirow[b]{2}{*}{ Indicators } & \multirow[b]{2}{*}{ Mass, $\mathrm{g}$} & \multirow[b]{2}{*}{ Width, cm } & \multirow[b]{2}{*}{ Length, cm } & \multirow{2}{*}{$\begin{array}{c}\text { Air cell height, } \\
\mathrm{mm}\end{array}$} & \multirow{2}{*}{$\begin{array}{c}\text { Egg shell mass, } \\
\mathrm{g}\end{array}$} & \multicolumn{3}{|c|}{ Egg shell thickness, mm } \\
\hline & & & & & & & Sharp end & Broad end & $\begin{array}{c}\text { Along the } \\
\text { meridian }\end{array}$ \\
\hline \multirow{5}{*}{ CG } & $\bar{X} \pm \overline{S_{x}}$ & $63.785 \pm 1.125$ & $4.465 \pm 0.021$ & $5.938 \pm 0.035$ & $2.431 \pm 0.007$ & $8.510 \pm 0.154$ & $0.474 \pm 0.024$ & $0.432 \pm 0.019$ & $0.438 \pm 0.019$ \\
\hline & $S$ & 8.715 & 0.165 & 0.272 & 0.037 & 0.846 & 0.130 & 0.107 & 0.107 \\
\hline & $\mathrm{Cv}$ & 13.663 & 3.693 & 4.575 & 1.529 & 9.942 & 27.391 & 24.709 & 24.364 \\
\hline & Ss & 0.796 & 0.015 & 0.025 & 0.005 & 0.109 & 0.017 & 0.014 & 0.014 \\
\hline & ScV & 1.248 & 0.337 & 0.418 & 0.197 & 1.283 & 3.534 & 3.188 & 3.144 \\
\hline \multirow{5}{*}{ EG } & $\overline{\bar{X}} \pm \overline{S_{x}}$ & $66.791 \pm 0.704$ & $4.474 \pm 0.020$ & $6.027 \pm 0.044$ & $2.334 \pm 0.004$ & $8.475 \pm 0.160$ & $0.298 \pm 0.011$ & $0.287 \pm 0.014$ & $0.299 \pm 0.012$ \\
\hline & $S$ & 5.454 & 0.151 & 0.342 & 0.023 & 0.877 & 0.061 & 0.078 & 0.065 \\
\hline & $\mathrm{Cv}$ & 8.166 & 3.381 & 5.680 & 0.978 & 10.345 & 20.305 & 27.134 & 21.667 \\
\hline & Ss & 0.498 & 0.014 & 0.031 & 0.003 & 0.113 & 0.008 & 0.010 & 0.008 \\
\hline & ScV & 0.746 & 0.309 & 0.519 & 0.126 & 1.335 & 2.620 & 3.501 & 2.796 \\
\hline
\end{tabular}

Analyzing the effect of a biologically active feed additive $\mid$ er consistency, which is indicated by the height of $23.96 \%$; the on the internal technological features of eggs, it has been found width is $2.14 \%$ more than that of the control group, with practiout that the egg white of the chicken eggs from EG had a dens- $\quad$ cally the same weight (Table 8).

Table 8

Technological features of egg yolk in laying hens

\begin{tabular}{|c|c|c|c|c|c|c|}
\hline Group & Indicators & Weight, $\mathrm{g}$ & Height, mm & Width, mm & Lungimea, $\mathrm{mm}$ & $\mathrm{pH}$ \\
\hline \multirow{5}{*}{ CG } & $\bar{X} \pm \overline{S_{x}}$ & $38.49 \pm 0.899$ & $6.47 \pm 0.225$ & $77.98 \pm 1.692$ & $94.27 \pm 2.155$ & $7.13 \pm 0.048$ \\
\hline & $S$ & 4.926 & 1.235 & 9.271 & 11.808 & 0.260 \\
\hline & $\mathrm{CV}$ & 12.797 & 19.071 & 11.889 & 12.526 & 3.651 \\
\hline & Ss & 0.636 & 0.159 & 1.196 & 1.524 & 0.034 \\
\hline & ScV & 1.651 & 2.461 & 1.534 & 1.616 & 0.471 \\
\hline \multirow{5}{*}{ EG } & $\overline{\bar{X}} \pm \overline{S_{x}}$ & $37.33 \pm 0.680$ & $8.02 \pm 0.474$ & $79.65 \pm 1.850$ & $94.93 \pm 2.379$ & $7.61 \pm 0.085$ \\
\hline & $S$ & 3.725 & 2.597 & 10.136 & 13.038 & 0.466 \\
\hline & $\mathrm{Cv}$ & 9.980 & 32.367 & 12.725 & 13.734 & 6.119 \\
\hline & Ss & 0.481 & 0.335 & 1.308 & 1.682 & 0.060 \\
\hline & ScV & 1.288 & 4.176 & 1.642 & 1.772 & 0.790 \\
\hline
\end{tabular}

Technological features of egg white in laying hens, $\bar{X} \pm \overline{S_{x}}$

\begin{tabular}{|c|c|c|c|c|c|c|c|}
\hline Group & Indicators & Weight, $\mathrm{g}$ & Height, $\mathrm{mm}$ & Width, $\mathrm{cm}$ & Length, $\mathrm{c} \mathrm{m}$ & $\mathrm{pH}$ & Color indicators \\
\hline \multirow{5}{*}{ CG } & $\overline{\bar{X}} \pm \overline{S_{x}}$ & $18.39 \pm 0.329$ & $16.05 \pm 0.502$ & $40.36 \pm 0.435$ & $43.34 \pm 0.271$ & $6.00 \pm 0.000$ & $8,77 \pm 3.007$ \\
\hline & $S$ & 1.806 & 2.750 & 2.384 & 1.483 & 0.000 & 16.481 \\
\hline & $\mathrm{Cv}$ & 9.819 & 17.138 & 5.906 & 3.422 & 0.000 & 140.063 \\
\hline & Ss & 0.233 & 0.355 & 0.308 & 0.191 & 0.000 & 2.127 \\
\hline & ScV & 1.267 & 2.211 & 0.762 & 0.442 & 0.000 & 18.073 \\
\hline \multirow{5}{*}{ EG } & $\bar{X} \pm \overline{S_{x}}$ & $17.58 \pm 0.294$ & $15.44 \pm 0.572$ & $40.99 \pm 0.384$ & $43.20 \pm 0.364$ & $6.00 \pm 0.000$ & $9.200 \pm 0.206$ \\
\hline & $S$ & 1.609 & 3.132 & 2.103 & 1.994 & 0.000 & 1.126 \\
\hline & $\mathrm{Cv}$ & 9.155 & 20.287 & 5.130 & 4.616 & 0.000 & 12.244 \\
\hline & Ss & 0.208 & 0.404 & 0.271 & 0.257 & 0.000 & 0.145 \\
\hline & ScV & 1.181 & 2.618 & 0.662 & 0.596 & 0.000 & 1.580 \\
\hline
\end{tabular}

The technological features of egg yolk in chickens from the experimental group were characterized by a decrease in weight by $0.81 \mathrm{~g}$ and by a higher colour intensity by 0.43 units.

The feed consumption was the same in the CG and EG, and the specific consumption per $1 \mathrm{~kg}$ of product varied from 1.55 to $1.70 \mathrm{~kg}$. Specific consumption (increase in feed conversion) was higher for EG by $1.80 \%$ compared to CG (Table 10).

Table 10

Specific consumption per $1 \mathrm{~kg}$ weight gain of broiler chickens

\begin{tabular}{|c|c|c|}
\hline \multirow{3}{*}{ Indicators } & \multicolumn{2}{|c|}{ Group } \\
\hline & CG & EG \\
\hline & Control & Experimenta \\
\hline $\begin{array}{l}\text { Compound feed consumption throughout } \\
\text { the period, } \mathrm{kg}\end{array}$ & 48000 & 48000 \\
\hline Egg production, pcs. & 9604.00 & 10278.0 \\
\hline
\end{tabular}

Conclusions. The high concentration of active ingredients and the uniqueness of the components of the peat feed supplement, the adsorbing properties due to the presence of humic acids and lignin in its composition, made it possible to increase the natural immune response in laying hens by increasing the egg production of laying hens by $7.2 \%$; by improving the quality of products such as the average egg weight by $4.72 \%$; egg mass by $12.6 \%$; the height of the egg white by $23.96 \%$; the width of the egg white by $2.14 \%$; and an increase in colour intensity by 0.43 units, while reducing the cost of food. 


\section{References:}

1. Adaptive resource-saving technology for the production of eggs [Text]: monograph / V.I. Fisinin, A. Sh. Karatashvili, I.A. Egorov et al. Sergiev Posad: Russian Scientofic Research and Technological Institute of Poultry (RSRTIP), 2016. - 351 p.; Balashov, V.V. Volgograd [Text]: monograph / V.V. Balashov, A.V. Balashov. - Volgograd: FGBOU VPO Volgograd GAU, 2013. 108 p.

2. Aliev SA Nitrogen fixation and physiological activity of soil organic matter. Novosibirsk: Nauka, 1988.145 p., Sokolov B.N., Kolesin V.N., Yampolsky A.L. et al. Peat in the national economy. M.: Nedra, 1988.268 p.

3. Biotechnology of livestock products: textbook and study manuals for students of higher educational institutions / M. Sh. Magomedov [and others]. Makhachkala: SUE "Printing House DNT RAN", 2011. 504 p.

4. Gorovaya A.I., Orlov D.S., Shcherbenko O.V. Humic substances. Kiev, 1995. 303.

5. Kalashnikov, A.P. et al., (2003) Norms and rations for feeding farm animals. - M. ISBN, 455.

6. Kobets AS, Stepchenko LM, Losєva €.O. Technical considerations of Ukraine TU U 15.7- 00493675-002: 2007 The feed additive is biologically active for the poultry "GSVD". 20.

7. Lupusor A., Gumene B. 2018. DCFTA in the Republic of Moldova. Free trade agreement with the European Union.

8. Martynov S.A. The effectiveness of the inclusion of untreated peat in the diet of feeding farm animals // Chemistry and computer modeling. Butlerov messages. - Syktyvkar, 2001.

9. Methodology for measuring the mass fraction of petroleum products in mineral, organogenic, organomineral soils and bottom sediments by IR spectrometry PND F 16.1: 2.2.22-98

10. Naumova LB, Gorlenko NP, Kazarin Al, Chemistry of Plant Raw Materials, 2003, 51-56.

11. Orlov D.S. Humic substances in the biosphere // Articles of the Sorovsk Educational Journal in text format. Chemistry. Moscow State University M.V. Lomonosov, 1997. Internet site http://www.pereplet.ru/obrazovanie/stsoros/260.html.

12. Ovsyannikov, A.I. (1976), Fundamentals of Experimental Business in Animal Husbandry. M. Kolos, 304.

13. Plokhinsky, N.P. (1969), A Guide to Biometrics for Livestock Technicians. M. Kolos, 256.

14. Stepchenko L.M., Efimov V.G., Loseva E.A., Skorik M.V. The use of humic preparations in the production of bioproducts. Tr. IV int. conf. Humic substances in the biosphere. St. Petersburg: Publishing house of St. Petersburg State University, 2007. P. 520-527. http://docplayer.ru/65078562- Ispolzovanie-guminovyh-preparatov-pri-poluchenii-bioprodukcii.html, 07.01.2021

15. primenenie-guminovyh-preparatov-v-zhivotnovodstve-obzor.pdf, 01.07.2021

Кайсин Лариса Григорівна, доктор сільськогосподарських наук, професор, директор департаменту управління тваринами та агро-продовольчої безпеки Державного аграрного університету Молдови (Кишинів, Молдова)

\section{Ефективність використання торфу як кормової добавки у змішаному кормі для курей}

В останні роки зріс інтерес до використання торфу в якості кормової добавки, зокрема, через його здатність запобігати кишковим захворюванням і стимулювати ріст тварин та птиці. Торф - легкодоступний природний матеріал $i$ джерело біологічно активних речовин, широко використовуваних не тільки у сільському господарстві, а й в медицині людини і тварин. Біологічна активність різних торф'яних препаратів пов'язана не тільки з коливаннями хімічного складу, але й з різними засобами застосування. Експеримент проводився на двох групах птиці в умовах птахофабрики Республіки Молдова. Метою було визначення використання кормової добавки - торф'яного концентрату в якості нового нетрадиційного кормового інгредієнта в складі комбікорму для курей-несучок та його вплив на їх несучість, середню вагу $і$ категорію яєць. До завдань дослідження входило вивчення хімічного складу торф'яної добавки і визначення впливу добавки порошкового торфу на несучість. Вивчено вплив дозування торф'яного препарату в кількості 1\% (дослідна група) $i$ отримані результати зіставлені з контрольною групою, в якій несучки споживали основний комбікорм. Висока концентрація діючих речовин і унікальність компонентів торф'яної кормової добавки, адсорбуючі властивості за рахунок наявності в ії складі гумінових кислот і лігніну дозволили підвищити природну імунну відповідь у курей-несучок за рахунок збільшення несучості на 7,2\%; за рахунок підвищення якості таких продуктів, як середня вага яєць на 4,72\%; яєчної маси на 12,6\%; висоту яєчного білка на 23,96\%; ширину яєчного білка на 2,14\% і збільшення інтенсивності забарвлення на 0,43 одиниці при зниженні вартості продуктів харчування.

Ключові слова: торф, кормова добавка, кури-несучки, яйця

Дата надходження до редакції: 13.04.2021 p. 